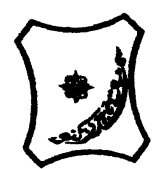

Bayero Journal of Pure and Applied Sciences, 9(1): 166 - 169

Received: November, 2015

Accepted: April, 2016

ISSN $2006-6996$

\title{
IMPACT OF SOME SAVANNA TREES ON SOIL QUALITY ON SMALLHOLDER FARMS IN A PART OF KANO, NIGERIA
}

\author{
Yakubu, I.* and Babatunde, B. $\mathrm{H}$. \\ Department of Geography Bayero University, PMB 3011, Kano \\ *Corresponding author: ibyakubu2006@yahoo.com
}

\begin{abstract}
Soil nutrient decline has become a major issue of concern to researchers in the semi-arid region of Nigeria. This condition is further exacerbated by worsening climate and declining environmental quality, amplified by huge population pressure on limited resources. This research investigates the impact of some key savanna tree species on soil quality on smallholder farms in a part of Kano, Nigeria. The results indicate that many indigenous tree species are deliberately left on these smallholder farms in a practice that may be referred to as agroforestry. Inventory of these trees indicates that Vitellaria paradoxa at 25\%, Parkia biglobosa at 20\%, and Anogeissus leiocarpus at $12 \%$, and Faidherbia albida at $8 \%$ are the dominant tree species on smallholder farms in the study area. Laboratory analysis of soil quality at different distances - $2 \mathrm{~m}, 6 \mathrm{~m}$ and beyond $6 \mathrm{~m}-$ around the inventoried trees on smallholder farms in the area indicated statistically significant differences in available soil minerals, at 0.02. Eighty-three percent of the farmers corroborated that crops close to trees perform better, in a social survey conducted on some 400 smallholder farmers in the study area. The study recommends: (1) deliberate promotion and regeneration of tree species, most especially leguminous, on smallholder farms; (2) more researches to determine and establish the specific distance(s) at which soil mineral elements are profoundly influenced by trees, and quantifying the actual soil mineral elements that may be made available by each of the different tree species.
\end{abstract}

Keywords: Agroforestry; Indigenous; Savanna; Smallholder

\section{INTRODUCTION}

The challenge of producing enough food for an ever increasing population has been one of the many issues facing mankind for a long time (Yakubu, 2010). One of the major biophysical causes of declining per capita food production, which remains alarming in marginal climates characterized by delicate ecosystems, has been reported to be the persistent decline in soil quality across the world (Balino et al., 2003). Semi-arid region of Nigeria, especially around Kano, are known for their low soil fertility and susceptibility to degradation, mostly through erosion and nutrient-mining (Abdu, 2013; Kowal and Kassam 1978). Socioeconomic problem of poverty is also a key issue in the region, with the smallholder rural farmers in the area generally lacking the capacity to tackle the endemic problem of low soil fertility with the addition of the hard to find or afford chemical fertilizers. This problem raises so much concern on the ability of the soils of the area to continue to be used for crop production sustainably. The area was long seen as a major agricultural hub in the semi-arid and coastal regions of West Africa. There is definitely a need to improve and maintain soil fertility in the area. One of the key ideas being proposed to address this problem across the dryland areas of the world has been that of incorporating trees with crops and/or animals, simultaneously or sequentially, through a system known as agroforestry. This practice of cropping within tree stands has been known for long in the Kano region (Cline-Cole et al, 1990).Smallholder agricultural production system is the oldest farming system in semi-arid northern Nigeria. A smallholder farm has been described by Essiet (1990) as a farm plot with an average size of 0.3 ha of land. These smallholder farms in the regioh 66 have an average of 4-5 trees. These trees have been described in many studies to interact with, and modify, the soil by increasing available mineral elements and physical quality (Adamu, 2012; Sanda and Atiku, 2013). The tree-soil interaction makes agroforestry system a viable tool for sustainable agricultural production. There is the need to closely re-evaluate tree-crop dynamics in the Nigeria's semiarid region, consequent upon the arrival of exotic tree species on smallholder farms. The changing quality of the landscape, brought about by the change in the density of some tree species due to Climate Change, wood fuel extraction and diseases (Yakubu, 2010) and lack of coordinated conservation measures are also strong reasons to promote trees on smallholder farms. There is also a need to differentiate where tree effects can be aggregated and where species-specific differences must be considered and understood (Rhoades, 1997). The specific objectives of this research are: (1) to establish an inventory of the changing tree species found on the smallholder farms in the area; (2) evaluate the changing quality of soil around trees on the smallholder farms under study. 


\section{MATERIALS AND METHODS Study Area}

This research was conducted in Rogo Local Government area of semi-arid region of Kano, Nigeria. It is located between latitudes $11^{\circ} 34^{\prime}$ and $11^{\circ} 56 \mathrm{~N}^{\prime}$ and between longitudes $7^{0} 50^{\prime}$ and $7^{0} 83^{\prime} \mathrm{E}$, occupying a land area of about $802 \mathrm{Km}^{2}$. Mean annual temperature of the area is about $26^{\circ} \mathrm{C}$, but Olofin (1987) indicated that mean monthly values range between $21^{\circ} \mathrm{C}$ in the coolest months (December/January) and $31^{\circ} \mathrm{C}$ in the hottest months (April/May). The soils of the area have been described by Kowal and Kassam (1978) as inherently low in fertility, with the exception of certain fadama or valley bottom alluvial of heavy texture, mostly located in the main river valleys and flood plains. The soils have equally been described to be highly erodible, and that serious erosion problems with intensive use of areas of undulating terrain are common (Olofin, 1987). The vegetation of the area is a woodland savanna type and an evident transition from Sudan Savanna to the Northern Guinea Savanna at the extreme southern part.

Agricultural land use in the area is characterized by smallholder cultivation. Mixed cropping with the integration of livestock is a popular practice. Crops such as grains and legumes are raised in small, widely scattered farm plots. The deliberate use of woody perennials is a long known traditional practice in the area. The study area is a major hub and supplier of agricultural produce to many parts of semi-arid and coastal West Africa.

\section{Research Design}

The research design for this work combined qualitative and quantitative approaches in data collection, handling and analysis. A comprehensive field survey was carried out to inventory the changing density and diversity of trees on smallholder farms in the area. Soil samples were equally collected at three different distances from trees available on the selected farms. Four districts were statistically selected from ten, for the purpose of the study. Subsequently four hundred smallholder farmers were also statistically identified and selected in the area for social surveys. Interviews and focus group discussion (FGD) were employed to complement information on crop-tree performance on farms with trees.

Soil Collection and Physico-Chemical Analysis

Soil samples were collected at $2 \mathrm{~m}, 6 \mathrm{~m}$ and further away from individual trees on smallholder farms. The location farther than $6 \mathrm{~m}$ from the farm trees served as control. Laboratory analysis was carried out on soils collected on the selected farms to quantify the mineral elements present in them with reference to their distances from the trees. Samples collected were tested in the laboratory for organic carbon, using the Walkey and Black (1934) method, phosphorous (P) content, using colorimeter method, exchangeable bases, with flame photometer, this was after using ammonium acetate extraction technique. Total nitrogen was determined using Kjeldal digestion method. Others include $\mathrm{pH}$, using 1:2.5 soil water ratios, particle size distribution, using hydrometer method, and cation exchange capacity was determined using the ammonium acetate saturation method.

\section{Data Analysis}

Inventory and percentage of the trees identified on smallholder farms were evaluated and recorded. Mean values were calculated for the results obtained from laboratory analysis of the soil and statistical analysis of Variance (ANOVA) was carried out, with reference to the mean values obtained at different points to the trees, using the Statistical Package for Social Science (SPSS) Software, 2015 Version.

\section{RESULTS AND DISCUSSION}

The most predominant tree on smallholder farms in the study area is Vitellaria paradoxa at $25 \%$. Parkia biglobosa (20\%), Anogeissus leiocarpus (12\%) and Faidherbia albida (8\%) were equally well noted on smallholder farms (Table 1). Other important savanna species like Diospyros mespilliformis at 4\%, among others, are not so common in the landscape of smallholder farms in the study area. Laboratory analysis of the soil samples collected showed that all the soils are slightly acidic, with the highest mean value of 6.43 , at the control point (Table 2). The soil samples collected at $2 \mathrm{~m}$ and $6 \mathrm{~m}$ have mean values of 5.87 and 6.07 respectively. When analysis of variance was carried out, significant difference was observed for the mean values of the soils at $2 \mathrm{~m}$ from the available tree species and the control point. Soil samples at $2 \mathrm{~m}$ and $6 \mathrm{~m}$ to available trees on smallholder farms, irrespective of the species, have no significant difference ( $p$ value $=0.02$ ) in this investigation. A similar finding was obtained and reported by Sanda and Atiku (2013).

For organic carbon (OC), there is significant difference between the soil collected at the control point and other distances across the smallholder farms. The highest mean value was recorded at $2 \mathrm{~m}$ point, with $1.62(\mathrm{cmol} / \mathrm{Kg})$, from the trees. The lowest mean value was obtained at the control point, with $1.22(\mathrm{cmol} / \mathrm{Kg})$. Available phosphorus (AVP) across the soil of the smallholder farms in the study area indicated significant difference ( $p$ value $=0.02$ ) between and among each of the distances soil samples were collected. Highest mean value was recorded at $2 \mathrm{~m}$ point, with $45.79 \mathrm{ppm}$ (Table 2 ). This significantly differed from samples collected at $6 \mathrm{~m}$ from the trees, at $43.63 \mathrm{ppm}$. The control point, with mean value of $40.13 \mathrm{ppm}$, equally differed from all the locations away for available trees on smallholder farms. 
Table 1: Available Trees on Smallholder Farms in a Part of Kano, Nigeria

\begin{tabular}{llc}
\hline Trees & Number of Trees & Percentage \\
\hline Vitellaria paradoxa & 85 & 25 \\
Parkia biglobosa & 68 & 20 \\
Anogeissus leiocarpus & 41 & 12 \\
Faidherbia albida & 27 & 8 \\
Tamarindus indica & 24 & 7 \\
Ficus platyphylla & 20 & 6 \\
Acacia nilotica & 20 & 6 \\
Balanites aegyptiaca & 20 & 6 \\
Ficus spp & 17 & 5 \\
Diospyros mespilliformis & 14 & 4 \\
Others & 3 & 1 \\
Total (\%) & 339 & 100 \\
\hline
\end{tabular}

Effective Cation Exchange Capacity (ECEC) showed that there is no significant difference between the samples from $2 \mathrm{~m}$ from the trees, at $23.13 \mathrm{cmol} / \mathrm{kg}$ ), and samples collected at $6 \mathrm{~m}$ from the trees, with $21.00 \mathrm{cmol} / \mathrm{kg}$. However, these two points are significantly different from the values obtained at the control point, with $17.33 \mathrm{cmol} / \mathrm{kg}$ ). This may imply that effective cation capacity declines away from available trees on smallholder farms in the study area.

The sodium content in the soil showed mean values for $2 \mathrm{~m}$ and $6 \mathrm{~m}$ away from the trees to be $0.1025 \mathrm{cmol} / \mathrm{kg}$ and $0.08 \mathrm{cmol} / \mathrm{kg}$ respectively, with no significant difference observed ( $p$ value $=0.02$ ). The soil at the control point, with $0.06 \mathrm{cmol} / \mathrm{kg}$, however has significant difference from the soil at $2 \mathrm{~m}$, but not for soil sample at $6 \mathrm{~m}$. Potassium level in the soil showed mean value at $2 \mathrm{~m}(0.1725 \mathrm{cmol} / \mathrm{kg})$, to be significantly different from mean value obtained at $6 \mathrm{~m}$, at $0.1283 \mathrm{cmol} / \mathrm{kg}$, and the control at $0.1083 \mathrm{cmol} / \mathrm{kg}$. This was similar to the findings of Sanda and Atiku (2013) in a work on the effect of Faidherbia albida on soil nutrients management in semi-arid Kano. Soils at $2 \mathrm{~m}$ and $6 \mathrm{~m}$ from the selected trees have mean values for calcium at $2.4258 \mathrm{cmol} / \mathrm{kg}$ and $2.3058 \mathrm{cmol} / \mathrm{kg}$ respectively. While these values were not significant, the value at the control, at $1.4775 \mathrm{cmol} / \mathrm{kg}$, showed significant difference from the two distances ( $2 \mathrm{~m}$ and $6 \mathrm{~m}$ ) across the smallholder farms in the study area.

Magnesium level in the soils collected at $2 \mathrm{~m}$ and $6 \mathrm{~m}$ from available smallholder farm trees showed no significant difference. Mean values around these two points, at $0.5 \mathrm{cmol} / \mathrm{Kg}$ and $0.4 \mathrm{cmol} / \mathrm{kg}$ respectively, manifested significant difference $(p$ value $=0.02$ ) from the mean value for the control, at $0.02 \mathrm{cmol} / \mathrm{kg}$. Total nitrogen in the soil from analysis showed mean value to be highest around $2 \mathrm{~m}$ from the tree, at $0.14 \%$, and the lowest mean value at $6 \mathrm{~m}$ from tree at $0.08 \%$. Analysis of variance showed no significant difference $(p$ value $=0.02$ ) between mean values obtained at $2 \mathrm{~m}$. This may be due to the presence of litter-fall from other adjoining trees on the most farms. This finding is similar to the findings of Adamu (2012).

The various results indicated higher mean values for soils collected $2 \mathrm{~m}$ from the smallholder farm trees, and mostly followed by the soil samples collected at $6 \mathrm{~m}$, except for soil $\mathrm{pH}$ level. Particle size distribution indicated that for sand, in the samples taken from $2 \mathrm{~m}$ from the available trees, recorded the highest mean value, at $22.52 \%$. There was no significant difference between the values obtained at $6 \mathrm{~m}$ and the control, with the mean values of $16.37 \%$ and $16.60 \%$ respectively. Mean silt value obtained at $2 \mathrm{~m}$ and $6 \mathrm{~m}$ from the available trees were $49.42 \%$ and $52.17 \%$ respectively, with the highest mean value obtained at the control with $54.42 \%$. Clay mean values at $6 \mathrm{~m}$ showed the highest value $(32.39 \%)$ than soils collected at $2 \mathrm{~m}$ from the tree $(30.14 \%)$ and soil at control $(27.14 \%)$.

Table 2: Chemical and Physical Properties of Soils around Trees on Smallholder Farms

\begin{tabular}{llll}
\hline Parameter & $\mathbf{2 m}$ & $\mathbf{6 m}$ & Control \\
\hline Soil pH & 5.87 & 6.07 & 6.43 \\
$\mathrm{OC}(\mathrm{cmol} / \mathrm{Kg})$ & 1.62 & 1.46 & 1.22 \\
$\mathrm{AVP}(\mathrm{ppm})$ & 45.79 & 43.63 & 40.14 \\
$\mathrm{ECEC}(\mathrm{cmol} / \mathrm{Kg})$ & 23.13 & 21.00 & 17.33 \\
$\mathrm{Na}(\mathrm{cmol} / \mathrm{Kg})$ & 0.1025 & 0.08 & 0.06 \\
$\mathrm{~K}(\mathrm{cmol} / \mathrm{Kg})$ & 0.1725 & 0.1283 & 0.1083 \\
$\mathrm{Ca}(\mathrm{cmol} / \mathrm{Kg})$ & 2.4258 & 2.3058 & 1.4775 \\
$\mathrm{Mg}(\mathrm{cmol} / \mathrm{Kg}$ & 0.05 & 0.04 & 0.02 \\
$\mathrm{~N}(\%)$ & 0.14 & 0.08 & 0.09 \\
Sand () & 22.5233 & 16.3792 & 16.6067 \\
Silt $(\%)$ & 49.42 & 52.17 & 54.42 \\
Clay $(\%)$ & 30.1425 & 32.3967 & 27.1425 \\
\hline
\end{tabular}

From the results obtained, soils closer to the available trees at $2 \mathrm{~m}$ were observed to have high mean values of mineral elements in the soil, which may be used by plants for proper growth (Rhoades, 1997). The farthest distance where samples was collected, beyond $6 \mathrm{~m}$, was found to be less in mean value of the 
same minerals. This supports the argument that the presence of these trees may have impact on the chemical content and physical characteristics of the soil and, hence its quality. Only the case of total nitrogen showed the control point as not significantly different from $2 \mathrm{~m}$ from the tree. This may be due to litter-fall from adjoining trees around the point, as similarly reported in the works of Adamu (2012) and Sanda and Atiku (2013).

Most trees found on the smallholder farms in the study area were leguminous, known for their ability to fix nitrogen and bring to the upper layer of the soil profile, mineral elements deep from the soil (Yakubu, 2010; Adamu, 2012; Sanda and Atiku, 2013). Interactions with some 400 smallholder farmers revealed that staple crops close to trees on their plots perform well in terms of yield, compared to those farther away from the trees. This further supports the idea that trees may interact with the soils on the farms, increasing the availability of mineral elements in the soil, allowing crops around them to benefit from the availability of these elements, for proper growth and development. As laboratory analyses have confirmed that some of these mineral elements are slightly higher closer to these trees, it may imply that the closer the crop to some of these trees the more it may access these elements, and the higher may be yield.

\section{REFERENCES}

Adamu, G. K. (2012): Use of Faidherbia albida for Soil Improvement in Smallholder Farming System of Gezawa L.G. Kano State, Nigeria. Res. J. Environ. Earth Sci. Vol4 (10) pp 895-899.

Abdu, E. B. (2013): Fuelwood Consumption and Desertification in Nigeria. International Journal of Science and Technology (3) 1.

Balino, A. B. Vanlauwe, kihara, J. and Kimetu, J. (2003): Use of Inorganic and Organic Fertilizers to Increase Land Sustainability and Productivity. CTA International Seminar on Information Support for Sustainable Soil Fertility Management.

Cline-Cole, R. A., Falola, J. A., Main, H. A. C., Mortimore, M. J., Nicole J. E. and O'Reilly. D. (1990): Woodfuel in Kano. Kano Rural Energy Research Group. Bayero University, Kano.

Essiet, E.U. (1990): A Comparison of Soil Degradation Under Smallholder Farming and Large Scale Irrigation Landuse in Kano State, Northern Nigeria. Land Degradation and Rehabilitation, 2:209-214.

Kawal, J.M. and Kassam, A.H. (1978): Agricultural Ecology of Savanna: $A$ Case Study of West Africa. Clarendon Press, Oxford. 430pp.

\section{CONCLUSION}

From the results, it has been shown that trees on smallholder farms in the study area have impact on the soil quality on such farms. The available soil minerals closer to the trees on the smallholder farms are found to be higher than those farther away. This places elements available for plant growth at these points. Therefore, farms with adequate trees may enhance crop performances. Leguminous trees found in the area like Faidherbia albida and Parkia biglobosa, among others, with ability to fix nitrogen and bring soil minerals from deep layers of the soil, may allow crops to thrive better on smallhloder farms. These findings, coupled with the farmers revelations of higher crop performance at points closer to trees, strengthened the possibilities that availability of trees on smallholder farms in the study area may avail such farms higher mineral elements.

\section{Recommendations}

The study recommends: (1) deliberate regeneration and promotion of tree species, most especially leguminous, on smallholder farms; (2) more researches to determine and establish the specific distance(s) at which soil mineral elements are profoundly influenced by trees, and quantifying the actual soil mineral elements that may be made available by each of the different trees species.

Olofin, A. E. (1987): Some Aspects of the Physical Geography of Kano Region and Related Human Responses. Departmental Lecture Series, Number 1. Bayero Uni., Kano.

Rhoades, C. C. (1997): Single-Tree Influences on Soil Properties in Agroforestry: Lessons from Natural Forest and Savanna Ecosystems. Agroforestry systems $\mathrm{L}_{\llcorner}$Vol 35 pp 71-94. Kluwer Academic Publishers.

Sanda, A. R. and Atiku M. (2013): Effect of Faidherbia albida on Soil Nutrients Management in the Semi-Arid Region of Kano State, Nigeria. International Journal of Science and Technology, Vol 2 (7) pp 201-203.

Walkey, A. and Black, A. (1934): Wet Oxidation Method for Measuring Active and Decomposable Organic Matter in Soil Sample. Journal of Soil Science, 37 pp 2-9

Weber, F. and Hopkins, M. (1983): Agroforestry in the Sahel: A Concept Paper Based on the Niamey Agroforestry Seminar. 23 May- 9 June 1983. Department of Sociology, Virginia Polytechnic Institute.

Yakubu, I. (2010): Climate Change Impact on the Density of Faidherbia albida on Smallholder Farms in the Degraded Lands of Kano, Northern Nigeria. Environmentalist, 30: 330 - 332. 